\title{
Undernutrition and stage of gestation influence fetal adipose tissue gene expression
}

Jacqueline M Wallace', John S Milne', Raymond P Aitken', Dale A Redmer ${ }^{\text {2 }}$, Lawrence P Reynolds ${ }^{2}$, Justin S Luther ${ }^{1,2}$, Graham W Horgan ${ }^{3}$ and Clare L Adam ${ }^{1}$

${ }^{1}$ Rowett Institute of Nutrition and Health, University of Aberdeen, Bucksburn, Aberdeen AB21 9SB, UK ${ }^{2}$ Department of Animal Sciences, North Dakota State University, Fargo, North Dakota 58108-6050, USA

${ }^{3}$ Biomathematics and Statistics Scotland, Aberdeen AB21 9SB, UK
Correspondence should be addressed to J M Wallace Email

Jacqueline.Wallace@ abdn.ac.uk

\begin{abstract}
Low birthweight is a risk factor for neonatal mortality and adverse metabolic health, both of which are associated with inadequate prenatal adipose tissue development. In the present study, we investigated the impact of maternal undernutrition on the expression of genes that regulate fetal perirenal adipose tissue (PAT) development and function at gestation days 89 and 130 (term = 145 days). Singleton fetuses were taken from adolescent ewes that were either fed control (C) intake to maintain adiposity throughout pregnancy or were undernourished (UN) to maintain conception weight but deplete maternal reserves ( $n=7$ /group). Fetal weight was independent of maternal intake at day 89 , but by day 130 , fetuses from UN dams were $17 \%$ lighter and had lower PAT mass that contained fewer unilocular adipocytes. Relative PAT expression of IGF1, IGF2, IGF2R and peroxisome proliferator-activated receptor gamma (PPARG) mRNA was lower in UN than in controls, predominantly at day 89 . Independent of maternal nutrition, PAT gene expression of PPARG, glycerol-3-phosphate dehydrogenase, hormone sensitive lipase, leptin, uncoupling protein 1 and prolactin receptor increased, whereas IGF1, IGF2, IGF1R and IGF2R decreased between days 89 and 130. Fatty acid synthase and lipoprotein lipase ( $L P L)$ mRNAs were not influenced by nutrition or stage of pregnancy. Females had greater $L P L$ and leptin mRNA than males, and $L P L$, leptin and PPARG mRNAs were decreased in UN at day 89 in females only. PAT gene expression correlations with PAT mass were stronger at day 89 than they were at day 130 . These data suggest that the key genes that regulate adipose tissue development and function are active beginning in mid-gestation, at which point they are sensitive to maternal undernutrition: this leads to reduced fetal adiposity by late pregnancy.
\end{abstract}
Key Words
- adipose tissue
- gene expression
$\checkmark$ fetal
- undernutrition
- sheep

Journal of Molecular Endocrinology (2015) 54, 263-275

\section{Introduction}

Prenatal growth restriction leading to low birthweight remains a global health issue, and in 2013, it was estimated to impact more than 22 million babies (16\%), with the highest incidence in Southeast Asia and Africa (http:// data.unicef.org/nutrition/low-birthweight). Maternal malnutrition involving deficits in macro- and micronutrients remains the major cause of low birthweight in developing countries (http://www.countdown2015mnch. org/documents/2013Report/Countdown_2013-Update_ withprofiles.pdf). Affected neonates have an increased risk

Published by Bioscientifica Ltd 
of neonatal mortality, whereas surviving infants have greater risk of life-restricting complications, including stunted growth, poor immune function and low educational attainment (Raqib et al. 2007, Longo et al. 2013, Christian et al. 2014). Furthermore, low birthweight predicts metabolic syndrome and obesity in adulthood, and these consequences are exacerbated if the postnatal environment is nutrient-rich, as is often the case in populations undergoing economic transition (Jain \& Singhal 2012). Similarly, in agriculturally important mammals (ruminants, pigs), there is evidence that maternal undernutrition is the primary determinant of poor prenatal growth, and reductions in birthweight are dependent on the timing, duration and severity of the nutritional insult, age and/or parity of the dam (Luther et al. 2005, Wu et al. 2006). For these species, low birthweight negatively impacts commercially important traits, including neonatal survival and carcass fat content, which result in decreased financial returns for the producer (Greenwood et al. 2010, Nissen \& Oksbjerg 2010).

In precocial mammals, appropriate prenatal adipose tissue development is essential for adequate thermoregulation at birth to ensure immediate survival. In addition, adipose tissue is central to energy metabolism throughout the life course (Klaus 2004, Galic et al. 2010), and derangements in its early development potentially impact body composition in later life. Accordingly, adipose tissue is considered to be a key target of developmental programming by maternal and/or fetal undernutrition (Sarr et al. 2012, Lukaszewski et al. 2013). In humans and sheep, adipose tissue is present from midgestation onwards, and most fat deposition occurs in the final third of pregnancy, predominately in the perirenal region (Gemmell \& Alexander 1978, Moragas \& Toran 1983). At mid-gestation, perirenal adipose tissue (PAT) is characterised by the rapid multiplication of precursor cells or preadipocytes (Pope et al. 2014), and by late pregnancy, this fat depot contains cells that have the appearance of both white (unilocular) and brown (multilocular) adipocytes (Gemmell \& Alexander 1978); these stages therefore reflect key windows in fetal fat development. In adults, unilocular adipocytes are the major sites of lipid storage and leptin secretion, and similarly in late gestation, plasma leptin in ovine fetuses correlates with unilocular fat mass when maternal nutrient intake is at or above maintenance requirements (Mühlhäusler et al. 2002). In contrast, multilocular adipocytes are predominantly associated with young animals; they are mitochondriarich and play an essential role in neonatal thermogenesis via a unique uncoupling protein 1 (UCP1) that burns fatty acids and glucose to release heat (Symonds 2013). Via its negative impact on fetal nutrient availability, maternal undernutrition may alter the relative proportions of white and brown fat in the fetus, which has implications for subsequent survival and body composition, but this hypothesis has not been tested. Published studies have examined selected molecular markers of adipose tissue growth, differentiation and function in the PAT of late-gestation sheep fetuses whose mothers were undernourished (UN) during specific windows of gestation, but no clear consensus has emerged regarding the impact of nutrition on fetal growth, PAT depot mass or gene expression (Symonds et al. 1998, Bispham et al. 2003, Budge et al. 2004, Lie et al. 2013).

In the present study, we address this deficit by examining PAT gene expression during both mid- and late pregnancy in a sheep model where maternal undernutrition throughout gestation reduced fetal weight, carcass fat content and PAT mass by late pregnancy (Luther et al. 2007). We examined genes involved in adipocyte proliferation and differentiation, namely, insulin-like growth factor 1 (IGF1), IGF2, IGF1R, IGF2R (Holly et al. 2006, Kleiman et al. 2013) and peroxisome proliferator-activated receptor gamma (PPARG), a transcriptional regulator that plays a central role in adipocyte differentiation and also co-ordinates the genes involved in lipid deposition and metabolism (Semple et al. 2006). These include lipogenic genes, such as lipoprotein lipase $(L P L)$, which enhances fatty acid uptake into adipocytes, fatty acid synthase $(F A S N)$, which catalyses fatty acid synthesis, and glycerol-3-phosphate dehydrogenase $(G 3 P D H)$, which is involved in glyceroneogenesis, as well as lipolytic genes, such as hormone sensitive lipase (HSL), which is involved in the hydrolysis of stored triglycerides to release non-esterified fatty acids (NEFAs). We also measured gene expression for leptin, because previous studies have suggested that it reflects the proportion of white adipose tissue in the fetus (Yuen et al. 2003), and also for $U C P 1$ and prolactin receptor (PRLR), which are markers of brown adipose tissue function (Pope et al. 2014). Accordingly, a secondary objective of the present study was to quantify the proportion of unilocular and multilocular cells in the PAT of fetuses from UN vs optimally nourished dams.

The present study tested the hypothesis that molecular markers of fetal adipose tissue development are temporally sensitive to maternal undernutrition and are associated with the resulting late-gestation lean fetal phenotype.

Published by Bioscientifica Ltd. 


\section{Materials and methods}

\section{Animals and sample derivation}

All of the procedures were licensed under the UK Animals (Scientific Procedures) Act of 1986 and were approved by the Local Ethical Review Committee. Day 4 embryos, which were recovered from adult ewes inseminated by a single sire, were transferred synchronously in singleton into adolescent recipients, as described previously (Wallace et al. 1997). Details of genotype, age, weight and adiposity of the animals, together with full details of the experimental design and diet composition have been presented previously (Luther et al. 2007). Briefly, recipients of equivalent age, weight and adiposity were individually offered optimal control (C) or a low quantity of the same complete diet $(\sim 0.7 \times$ control intake) following embryo transfer. The control dietary level aimed to maintain normal maternal adiposity throughout gestation (promoting liveweight gain of $\sim 50 \mathrm{~g} /$ day) and to provide $100 \%$ of the nutrient requirements of the adolescent sheep carrying a singleton fetus according to the stage of pregnancy (AFRC 1993). The low dietary intake was calculated to maintain maternal liveweight at the initial value and to thereby deplete maternal reserves throughout gestation as the dam attempted to meet the nutrient requirements of the developing conceptus: these dams were considered undernourished (UN). The level of feed offered was reviewed three times per week and adjusted as appropriate according to weekly data on bodyweight change. Maternal body condition was subjectively assessed on a five-point scale fortnightly by the same highly experienced operator (1, emaciated and 5, obese; Russel et al. 1969). This score provides an external measure of adiposity, and it is highly correlated with maternal carcass fat as determined by chemical analysis (Wallace et al. 1999). Ultrasonography at 45 days gestation revealed 28 viable pregnancies.

Immediately before necropsy, maternal venous blood was sampled and the plasma was used to confirm metabolic status, namely, glucose, insulin and NEFA concentrations. Ewes were killed on either day 89 or 130 gestation ( $n=7 /$ stage per group; term $=145$ days) by i.v. sodium pentobarbitone $(20 \mathrm{ml}$ Euthesate, $200 \mathrm{mg}$ pentobarbito$\mathrm{ne} / \mathrm{ml}$; Willows Francis Veterinary, Crawley, UK) and exsanguination. The gravid uterus was weighed and opened, and fetal blood was sampled by cardiac puncture immediately before intracardiac sodium pentobarbitone was administered ( $3 \mathrm{ml}$ Euthesate); this plasma was analysed for glucose and insulin. The fetus was dried and weighed. The PAT was weighed, and samples were either snap-frozen in isopentane chilled by liquid nitrogen and stored at $-80{ }^{\circ} \mathrm{C}$ until gene expression analysis (days 89 and 130) or fixed in $10 \%$ neutral buffered formalin and embedded in paraffin for the histological quantification of adipocytes (day 130 only). Intact placentomes were dissected and weighed. The maternal carcass was weighed to confirm the effectiveness of nutritional treatments. The fat content of fetal carcasses was determined by chemical analysis (Wallace et al. 2006).

\section{Plasma analyses}

Maternal plasma NEFA was measured using an automated clinical analyser with kits supplied by the manufacturer (Labmedics, Manchester, UK), with a variation between duplicates of $<5 \%$. Maternal and fetal insulin was measured by RIA (MacRae et al. 1991; duplicate variation $<10 \%$ ), and glucose was measured by a dual-biochemistry analyser (YSI model 2700, Yellow Springs, OH, USA; duplicate variation $<3 \%$ ).

\section{Fetal adipocyte histology}

The method used to quantify the density of unilocular and multilocular cells in fetal PAT matched that of Mühlhäusler et al. (2002). Sections were cut $(5 \mu \mathrm{m})$, dried overnight, stained with haematoxylin and eosin and viewed at $200 \times$ magnification using a Leica microscope. Twelve separate complete fields of view per animal, which were $\sim 1 \mathrm{~mm}$ apart on a single section, were captured by a digital camera, and the images were analysed using ImagePro Plus version 4.5.1 (Media Cybernetics, Inc., Silver Spring, MD, USA). Standard point counting techniques (Wiebel 1979) were employed: a standard grid was used to determine the adipose tissue component (i.e. unilocular or multilocular cell) that fell below each of 35 grid points/ image; there was thus a total of 420 points/animal. The volume density $\left(V_{\mathrm{d}}\right)$ of each cell type was calculated as $V_{\mathrm{d}}=N / T$, where $N$ was the number of points that fell on unilocular or multilocular cells and $T$ was the total number of points counted. The total mass of the unilocular or multilocular component was calculated by multiplying the $V_{\mathrm{d}}$ of each component by the PAT mass. Relative unilocular (or multilocular) fat mass ( $\mathrm{g} / \mathrm{kg}$ fetus) was calculated by dividing by fetal weight.

\section{Quantitative real-time RT-PCR analysis}

mRNA for genes involved in adipocyte proliferation (IGF1, $I G F 2, I G F 1 R$ and $I G F 2 R)$ and adipocyte differentiation and function (PPARG, G3PDH, LPL, FAS, HSL, UCP1, PRLR and

Published by Bioscientifica Ltd. 
leptin) in fetal PAT was measured by quantitative real-time RT-PCR using probe and primer sets for sheep-specific sequences of these genes as previously described (Matsuzaki et al. 2006, Wallace et al. 2014). Briefly, total RNA was extracted from $100 \mathrm{mg}$ frozen PAT using an RNeasy Lipid Tissue Mini Kit (Qiagen). The quality and quantity of total RNA was determined via capillary electrophoresis using an Agilent 2100 Bioanalyzer (Agilent Technologies, Wilmington, DE, USA). Real-time RT-PCR reagents, probes and primers were purchased from and used as recommended by Applied Biosystems. For each sample, $54 \mathrm{ng}$ total RNA was subjected to RT in triplicate to generate first-strand cDNA using TaqMan RT Reagents and Multiscribe Reverse Transcriptase. Polymerisation and amplification reactions for each RT sample were performed in duplicate in $20 \mu \mathrm{l}$ final volume using the 7500 Fast RealTime PCR system (Applied Biosystems). Quantification was performed using a relative standard curve method with serial dilutions of reference standard cDNA generated from RNA pooled from the PAT of control and UN fetuses (three per stage per group). Individual mRNA levels of genes of interest were expressed relative to the sample's own internal 18S RNA, which was determined using human $18 \mathrm{~S}$ Pre-Developed TaqMan Assay Reagents. Samples were randomised to ensure that each nutritional treatment and sex was represented in each of four 96-well plates. Also, a quality control sample generated from this RNA pool was run on each plate and used to calculate inter- and intra-assay coefficients of variation (CV). Intra-plate CV varied from 3.9 to $6.5 \%$ (mean \pm s.E.M. $5.3 \pm 0.23$ ), whereas inter-plate $\mathrm{CV}$ varied from 0.76 to $10.76 \%(7.1 \pm 0.80)$.

\section{Statistical analysis}

The power calculation carried out for the original study was based on the prediction that maternal undernutrition would impact fetal growth by the late-gestation time point. Accordingly, seven animals per group were selected so that the experiment would have $80 \%$ power to detect (at $5 \%$ significance) a $20 \%$ change in fetal weight of $870 \mathrm{~g}$, assuming animal variability of $515 \mathrm{~g}$. This was based on fetal weight data obtained from control-fed adolescent ewes that were the same genotype, had identical paternal genetics and were at the same stage of gestation. Statistical comparisons were made using Minitab 16 (Minitab, Inc., State College, PA, USA). ANOVA (general linear model) was used to determine the effects of maternal nutrition and gestational stage, both independently and interacting, on maternal and fetal phenotype (Table 1) and on fetal PAT gene expression (Table 2). Post hoc comparisons used Tukey's method when one of the main effects or their interaction was significant. We had no control over the sex of the embryo/fetus and the study was accordingly not originally powered to examine sex effects; however, sexspecific effects were apparent upon initial examination of the data, and we therefore additionally included sex as

Table 1 Maternal and fetal phenotype at necropsy on days 89 and 130 of gestation in relation to maternal nutrition ( $n=7 / g$ roup). Values are group means \pm S.E.M.

\begin{tabular}{l} 
Stage of gestation \\
\hline Maternal nutrition \\
\hline Maternal \\
Change in adiposity \\
Liveweight $(\mathrm{kg})^{\mathrm{c}}$ \\
Carcass weight $(\mathrm{kg})$ \\
Plasma glucose $(\mu \mathrm{mol} / \mathrm{l})$ \\
Plasma insulin $(\mathrm{ng} / \mathrm{ml})$ \\
Plasma NEFA (mmol/ml) \\
Fetal \\
Weight (g) \\
Total placentome weight (g) \\
Brain:liver ratio \\
Plasma glucose $(\mu \mathrm{mol} / \mathrm{l})$ \\
Plasma insulin $(\mathrm{ng} / \mathrm{ml})$ \\
Perirenal fat weight $(\mathrm{g})$ \\
Perirenal fat $(\mathrm{g} / \mathrm{kg}$ fetus)
\end{tabular}

\begin{tabular}{c}
\hline Day \\
\hline Control \\
\hline \\
$0.0 \pm 0.0^{\mathrm{A}}$ \\
$46.4 \pm 0.67^{\mathrm{A}}$ \\
$23.4 \pm 0.48^{\mathrm{A}}$ \\
$3.18 \pm 0.125^{\mathrm{A}}$ \\
$0.69 \pm 0.058^{\mathrm{A}}$ \\
$0.30 \pm 0.077^{\mathrm{A}}$ \\
$657 \pm 30^{\mathrm{A}}$ \\
$665 \pm 75^{\mathrm{A}}$ \\
$0.314 \pm 0.017^{\mathrm{A}}$ \\
$0.49 \pm 0.038^{\mathrm{A}}$ \\
$0.44 \pm 0.022$ \\
$2.1 \pm 0.29^{\mathrm{A}}$ \\
$3.3 \pm 0.52^{\mathrm{A}}$ \\
\hline
\end{tabular}

Day 89

UN

$-0.4 \pm 0.05^{\mathrm{B}}$
$42.3 \pm 1.12^{\mathrm{B}}$
$20.5 \pm 0.71^{\mathrm{B}}$
$2.99 \pm 0.055^{\mathrm{A}, \mathrm{B}}$
$0.53 \pm 0.031^{\mathrm{A}, \mathrm{B}}$
$0.26 \pm 0.039^{\mathrm{A}}$

$$
597 \pm 43^{A}
$$$$
607+28^{\mathrm{A}, \mathrm{B}}
$$

$0.359 \pm 0.020^{A, B}$

$0.47 \pm 0.055^{\mathrm{A}}$

$0.44 \pm 0.019$

$1.45 \pm 0.33^{\mathrm{A}}$

$2.3 \pm 0.34^{\mathrm{A}}$

\begin{tabular}{c}
\hline Day 130 \\
\hline Control \\
\hline \\
$0.0 \pm 0.0^{\mathrm{A}}$ \\
$49.6 \pm 0.58^{\mathrm{A}}$ \\
$24.8 \pm 0.60^{\mathrm{A}}$ \\
$3.29 \pm 0.098^{\mathrm{A}}$ \\
$0.75 \pm 0.090^{\mathrm{A}}$ \\
$0.38 \pm 0.051^{\mathrm{A}, \mathrm{B}}$ \\
$4274 \pm 84^{\mathrm{B}}$ \\
$480 \pm 28^{\mathrm{B}}$ \\
$0.313 \pm 0.025^{\mathrm{A}}$ \\
$0.39 \pm 0.076^{\mathrm{A}, \mathrm{B}}$ \\
$0.47 \pm 0.083$ \\
$27.4 \pm 1.11^{\mathrm{B}}$ \\
$6.4 \pm 0.23^{\mathrm{B}}$ \\
\hline
\end{tabular}

\begin{tabular}{c}
130 \\
\hline UN \\
$-0.7 \pm 0.06^{C}$ \\
$41.3 \pm 0.93^{B}$ \\
$18.9 \pm 0.53^{B}$ \\
$2.75 \pm 0.062^{B}$ \\
$0.39 \pm 0.046^{B}$ \\
$0.76 \pm 0.187^{B}$ \\
$3555 \pm 152^{C}$ \\
$469 \pm 39^{B}$ \\
$0.441 \pm 0.031^{B}$ \\
$0.22 \pm 0.030^{B}$ \\
$0.29 \pm 0.038$ \\
$19.5 \pm 1.01^{C}$ \\
$5.5 \pm 0.33^{B}$ \\
\hline
\end{tabular}

\begin{tabular}{|c|c|c|}
\hline \multicolumn{3}{|c|}{$P$ value ${ }^{a}$} \\
\hline Stage & Nutrition & Interaction \\
\hline 0.001 & 0.000 & 0.001 \\
\hline 0.236 & 0.000 & 0.024 \\
\hline 0.769 & 0.000 & 0.019 \\
\hline 0.484 & 0.000 & 0.057 \\
\hline 0.481 & 0.000 & 0.127 \\
\hline 0.012 & 0.129 & 0.063 \\
\hline 0.000 & 0.000 & 0.002 \\
\hline 0.002 & 0.595 & 0.751 \\
\hline 0.107 & 0.003 & 0.101 \\
\hline 0.004 & 0.076 & 0.150 \\
\hline 0.215 & 0.076 & 0.086 \\
\hline 0.000 & 0.000 & 0.000 \\
\hline 0.000 & 0.019 & 0.890 \\
\hline
\end{tabular}

UN, undernourished; NEFA, non-esterified fatty acids.

${ }^{a}$ Post hoc comparisons (Tukey's method) was used to further differentiate between four groups; thus, within rows values with different superscript letters differ at $P<0.05$.

${ }^{b}$ Change in external adiposity score from embryo transfer to necropsy.

CLiveweight minus weight of gravid uterus at necropsy. 
Table 2 Fetal perirenal fat gene expression at necropsy on days 89 and 130 of gestation in relation to maternal nutrition ( $n=7 /$ group). Values are group means \pm s.E.M.

\begin{tabular}{l}
\hline Stage of gestation \\
\hline Maternal nutrition \\
\hline Male:female ratio \\
18S \\
PPARG/18S \\
G3PDH/18S \\
LPL/18S \\
FASN/18S \\
HSL/18S \\
Leptin/18S \\
UCP1/18S \\
PRLR/18S \\
IGF1/18S \\
IGF2/18S \\
IGF1R/18S \\
IGF2R/18S
\end{tabular}

\begin{tabular}{|c|c|}
\hline \multicolumn{2}{|c|}{ Day 89} \\
\hline Control & UN \\
\hline $3: 4$ & \\
\hline $0.023 \pm 0.001$ & $0.024 \pm 0.001$ \\
\hline $20.6 \pm 1.89^{A, B}$ & $15.6 \pm 1$ \\
\hline $20.9 \pm 2.21^{\mathrm{A}}$ & $18.8 \pm$ \\
\hline $27.6 \pm 4.11$ & 2 \\
\hline $22.6 \pm$ & $21.2 \pm 2.47$ \\
\hline $10.6 \pm 2.09^{\mathrm{A}}$ & $7.7 \pm 0.87^{\mathrm{A}}$ \\
\hline $34.9 \pm 5.97^{A, B}$ & $23.8 \pm$ \\
\hline $0.53 \pm 0.07^{\mathrm{A}}$ & $0.38 \pm 0.08^{A}$ \\
\hline $0.9 \pm 0.12^{A}$ & $0.9 \pm 0.15^{A}$ \\
\hline $30.5 \pm 1.48^{\mathrm{A}}$ & $23.1 \pm 1.83^{\mathrm{A}}$ \\
\hline $35.3 \pm 2.36^{\mathrm{A}}$ & $27.0 \pm 2.49^{\mathrm{A}}$ \\
\hline $14.6 \pm 1.10^{\mathrm{A}}$ & $11.8 \pm 1.12^{\mathrm{A}, \mathrm{B}}$ \\
\hline $21.8 \pm 1.57^{A}$ & $16.1 \pm 1.67$ \\
\hline
\end{tabular}

\begin{tabular}{ccc}
\multicolumn{2}{c}{ Day 130} \\
\cline { 1 - 2 } Control & & UN \\
\cline { 1 - 1 } $3: 4$ & & $3: 4$ \\
$0.024 \pm 0.001$ & & $0.024 \pm 0.001$ \\
$22.3 \pm 1.25^{\mathrm{B}}$ & $23.8 \pm 1.49^{\mathrm{B}}$ \\
$41.9 \pm 2.95^{\mathrm{B}}$ & & $50.8 \pm 3.29^{\mathrm{B}}$ \\
$24.8 \pm 1.96$ & & $26.8 \pm 2.73$ \\
$27.4 \pm 3.57$ & & $20.9 \pm 2.00$ \\
$36.9 \pm 1.48^{\mathrm{B}}$ & & $43.5 \pm 3.41^{\mathrm{B}}$ \\
$47.9 \pm 5.08^{\mathrm{A}}$ & & $40.3 \pm 3.96^{\mathrm{A}, \mathrm{B}}$ \\
$37.3 \pm 3.05^{\mathrm{B}}$ & & $33.9 \pm 2.94^{\mathrm{B}}$ \\
$25.6 \pm 3.26^{\mathrm{B}}$ & & $26.1 \pm 2.84^{\mathrm{B}}$ \\
$10.9 \pm 3.30^{\mathrm{B}}$ & $5.9 \pm 0.32^{\mathrm{B}}$ \\
$9.0 \pm 2.76^{\mathrm{B}}$ & $7.1 \pm 0.41^{\mathrm{B}}$ \\
$8.9 \pm 0.50^{\mathrm{B}}$ & $8.4 \pm 0.64^{\mathrm{B}}$ \\
$8.1 \pm 1.18^{\mathrm{C}}$ & $7.5 \pm 0.68^{\mathrm{C}}$ \\
\hline
\end{tabular}

\begin{tabular}{|c|c|c|}
\hline \multicolumn{3}{|c|}{$P$ value $^{a}$} \\
\hline Stage & Nutrition & Interaction \\
\hline 0.551 & 0.214 & 0.150 \\
\hline 0.003 & 0.266 & 0.042 \\
\hline 0.000 & 0.213 & 0.051 \\
\hline 0.578 & 0.415 & 0.142 \\
\hline 0.973 & 0.433 & 0.423 \\
\hline 0.000 & 0.423 & 0.047 \\
\hline 0.004 & 0.056 & 0.708 \\
\hline 0.000 & 0.431 & 0.469 \\
\hline 0.000 & 0.905 & 0.901 \\
\hline 0.000 & 0.006 & 0.563 \\
\hline 0.000 & 0.031 & 0.163 \\
\hline 0.000 & 0.082 & 0.204 \\
\hline 0.000 & 0.025 & 0.067 \\
\hline
\end{tabular}

UN, undernourished.

${ }^{a}$ Post hoc comparisons (Tukey's method) were used to further differentiate between the four groups; thus, within rows values with different superscript letters differ at $P<0.05$.

a factor in a second three-factor ANOVA (nutrition $\times$ stage $\times$ sex, and all possible interactions). We present the relevant findings from this analysis separately. Paired Student's $t$-tests were used to determine differences in adipocyte cell type at day 130 (Table 3). Pearson productmoment correlation was used to explore relationships between variables where indicated. Values are group means \pm s.E.M. throughout; statistical significance was taken as $P<0.05$, and a trend was indicated where $P=0.06-0.1$.

\section{Results}

\section{Maternal and fetal phenotype}

By design, maternal liveweight $(42.9 \pm 0.41 \mathrm{~kg})$ and adiposity score $(2.3 \pm 0.02)$ were equivalent between groups at embryo transfer; thereafter, the dams that received a control intake maintained their initial adiposity score until necropsy at gestational day 89 or 130 (Table 1). In contrast, the external adiposity score of UN dams gradually decreased, with the changes being equivalent to an average loss of 6.2 and $8.8 \%$ body fat at days 89 and 130 respectively (Russel et al. 1969). Maternal liveweight and carcass mass had diverged by day 89 , and the difference between nutritional groups increased by day 130. The relatively catabolic state of UN dams was mirrored by low plasma insulin and glucose, and plasma NEFA was increased in UN vs control dams by late pregnancy.

Fetal weight was independent of maternal dietary intake at day 89 , but by day 130 , fetuses from UN dams were $17 \%$ lighter than those in control dams (Table 1); however, brain growth was preserved as was indicated by

Table 3 Unilocular and multilocular adipose cell distribution in the fetal perirenal fat depot at day 130 of gestation in relation to maternal nutrition ( $n=7 /$ group). Values are group means \pm s.E.M.

\begin{tabular}{l} 
Maternal nutrition \\
\hline Unilocular fat \\
Volume density (\%) \\
Total mass $(\mathrm{g})$ \\
Relative mass ( $/ \mathrm{kg}$ fetus) \\
Multilocular fat \\
Volume density (\%) \\
Total mass (g) \\
Relative mass (g/kg fetus) \\
\hline
\end{tabular}

$\begin{array}{r}\hline \text { Control } \\ \hline \\ \\ 14.3 \pm 3.79 \\ 3.3 \pm 0.26 \\ 48.6 \pm 3.81 \\ 13.4 \pm 1.37 \\ 3.1 \pm 0.29 \\ \hline\end{array}$

\begin{tabular}{c}
\hline UN \\
\hline $41.9 \pm 4.47^{\star}$ \\
$8.2 \pm 1.01^{\dagger}$ \\
$2.4 \pm 0.37$ \\
$58.0 \pm 4.47^{\star}$ \\
$11.3 \pm 0.96^{\dagger}$ \\
$3.1 \pm 0.18$ \\
\hline
\end{tabular}

$P$ value, control vs UN

0.137

0.002

0.078

0.135

0.231

0.954

UN, undernourished. Within a nutritional group, values with the same symbol differ from each other, $P<0.05$.

http://jme.endocrinology-journals.org DOI: 10.1530/JME-15-0048
(C) 2015 Society for Endocrinology Printed in Great Britain
Published by Bioscientifica Ltd 
higher fetal weight-specific brain weight $(12.0 \pm 0.39 \mathrm{~g} / \mathrm{kg}$ vs $9.9 \pm 0.35 \mathrm{~g} / \mathrm{kg}, P<0.01)$ as well as greater brain:liver weight ratios (Table 1). Fetal plasma insulin and glucose were independent of maternal nutrition at day 89, but there were trends towards lower insulin and glucose in the UN group at day 130. Total placentome weight was not affected by maternal nutrition at either time point (Table 1).

\section{Fetal adiposity}

Absolute PAT mass increased $>12$-fold between gestational days 89 and 130 and was lower in fetuses of UN dams at the late-gestation time point (Table 1). Moreover, PAT mass was positively related to fetal weight at both gestational ages $(n=14 ; r=0.632, P=0.015$ and $r=0.738$, $P=0.003$, at days 89 and 130 respectively), and fetal weight-specific PAT mass was accordingly also negatively impacted by maternal undernutrition. At gestation day 130 , both absolute and fetal weight-specific unilocular fat cell mass were lower in fetuses from UN vs control dams (Table 3), but there were no significant effects of nutrition on multilocular cell mass. Representative images are presented in Fig. 1. The relative proportion (volume density) of unilocular vs multilocular cells was equivalent within the control group, but UN fetuses had more multilocular than unilocular cells $(P<0.05)$. Irrespective of maternal nutrition, absolute and relative fetal unilocular fat mass was positively associated with carcass fat percentage $(n=14 ; r=0.806, P=0.001$ and $r=0.763$, $P=0.001$; Fig. 1C). Multilocular fat cell mass was unrelated to fetal carcass fat percentage, but total multilocular fat mass was positively associated with fetal weight $(n=14$; $r=0.605, P=0.022$; Fig. 1D), primarily because of the UN group $(n=7, r=0.787, P=0.036)$.

\section{Perirenal fat gene expression}

The two-factor ANOVA revealed an increase in PPARG mRNA expression in PAT as gestation progressed, whereas the stage $\times$ nutrition interaction reflected lower PPARG mRNA abundance in the UN group at gestational day 89 but not at day 130 (Table 2). G3PDH and HSL mRNA expression increased two- to threefold between days 89 and 130 irrespective of maternal nutrition, whereas $L P L$ and FAS mRNA levels were independent of both gestational age and nutrition. UCP1 and PRLR mRNA were virtually undetectable at day 89 and independent of maternal nutrition at day 130 . In contrast, gene expression for IGF1, IGF2 and their receptors was robustly greater at day 89 than it was at day 130, and these genes were impacted by maternal nutrition, largely because of the lower expression in UN fetuses at day 89. PAT leptin mRNA was influenced by stage of pregnancy (day $130>$ day 89), and there was a trend for lower expression in UN fetuses.

In view of the differential in fetal weight and PAT mass between the two stages of pregnancy and the dominant influence of gestational age on the mRNA abundance of the majority of the genes quantified, the relationships between fetal weight, PAT mass, metabolic status and adipose tissue gene expression were examined separately for the day 89 and the 130 groups (Table 4). At day 89, the relative expression of the genes involved in adipocyte differentiation and function, namely, PPARG, G3PDH, $L P L, F A S N$, HSL, leptin and $U C P 1$, were positively related to both absolute and fetal weight-specific PAT mass, but they were unrelated to fetal weight (Table 4 and Fig. 2). Of the genes that are putatively involved in adipocyte proliferation, only IGF1 was weakly positively related to fetal weight-specific PAT mass. Also at day 89 , fetal plasma glucose was unrelated to the abundance of any of the
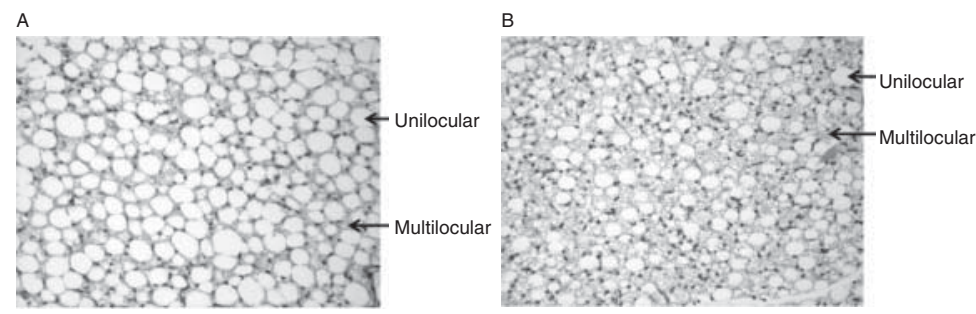

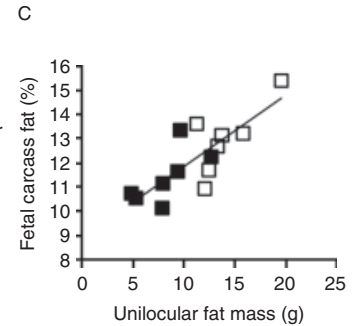

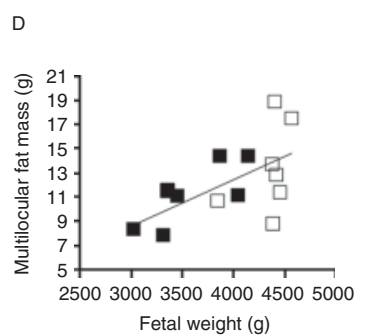

\section{Figure 1}

Haematoxylin and eosin-stained sections of perirenal fat from a representative fetus from a control and an undernourished (UN) pregnancy (both females) with unilocular and multilocular fat cells highlighted $(A$ and $B)$. The relationship between perirenal unilocular fat mass and (c) 2015 Society for Endocrinology Printed in Great Britain the percentage of fat in the carcass $(C ; r=0.806, P=0.001)$ and the relationship between fetal weight and multilocular fat mass ( $) r=0.605$, $P=0.022$ ) at day 130 of gestation in fetuses from control (open square) and UN (filled square) adolescent dams.

Published by Bioscientifica Ltd. 
Table 4 Relationship between perirenal fat gene expression (relative to 18S) and fetal weight, fat mass and metabolic status at days 89 and 130 of gestation, irrespective of maternal nutrition and sex

\begin{tabular}{|c|c|c|c|c|c|c|c|c|c|c|c|}
\hline & PPARG & G3PDH & LPL & FASN & HSL & Leptin & UCP1 & IGF1 & IGF2 & IGF1R & IGF2R \\
\hline \multicolumn{12}{|l|}{ Day 89} \\
\hline Fetal weight (g) & 0.137 & 0.139 & 0.161 & 0.333 & 0.274 & 0.122 & 0.203 & 0.257 & 0.189 & -0.132 & 0.066 \\
\hline $\begin{array}{l}\text { Perirenal fat } \\
\text { mass }(\mathrm{g})\end{array}$ & $0.619 *$ & $0.636 *$ & $0.707^{\dagger}$ & $0.807^{\ddagger}$ & $0.770^{\ddagger}$ & $0.759^{\dagger}$ & $0.630^{*}$ & 0.505 & 0.389 & -0.060 & 0.325 \\
\hline $\begin{array}{r}\text { Perirenal fat } \\
\text { (g/kg fetus) }\end{array}$ & $0.729^{\dagger}$ & $0.717^{\dagger}$ & $0.795^{\ddagger}$ & $0.808^{\ddagger}$ & $0.805^{\ddagger}$ & $0.872^{\ddagger}$ & $0.702^{\dagger}$ & $0.558 *$ & 0.442 & 0.049 & 0.420 \\
\hline Plasma glucose & -0.207 & -0.282 & -0.233 & -0.177 & -0.166 & -0.215 & -0.397 & -0.105 & -0.075 & -0.323 & -0.234 \\
\hline Plasma insulin & -0.497 & -0.413 & $-0.584^{*}$ & $-0.538^{*}$ & $-0.696^{\dagger}$ & -0.489 & $-0.697^{\dagger}$ & -0.377 & -0.436 & -0.205 & -0.400 \\
\hline \multicolumn{12}{|l|}{ Day 130} \\
\hline Fetal weight (g) & -0.422 & $-0.560 *$ & -0.511 & 0.239 & $-0.612 *$ & 0.015 & 0.003 & 0.390 & 0.093 & -0.061 & -0.047 \\
\hline $\begin{array}{l}\text { Perirenal fat } \\
\text { mass }(\mathrm{g})\end{array}$ & -0.328 & $-0.570 *$ & -0.315 & 0.193 & $-0.549 *$ & 0.179 & 0.421 & 0.483 & 0.267 & 0.093 & 0.140 \\
\hline $\begin{array}{r}\text { Perirenal fat } \\
\text { (g/kg fetus) }\end{array}$ & -0.064 & -0.315 & 0.010 & 0.084 & -0.222 & 0.208 & $0.594^{*}$ & 0.343 & 0.295 & 0.161 & 0.221 \\
\hline Plasma glucose & 0.172 & 0.215 & 0.1 & 0.3 & -0.1 & $0.689^{\dagger}$ & 0.2 & $0.879^{\ddagger}$ & $0.796^{\dagger}$ & $0.631 *$ & $0.741^{\dagger}$ \\
\hline Plasma insulin & -0.059 & -0.137 & 0.129 & 0.016 & -0.241 & $0.716^{\dagger}$ & 0.192 & $0.597^{*}$ & 0.477 & 0.449 & 0.475 \\
\hline
\end{tabular}

Values are Pearson correlation coefficients with significant values shown in bold, ${ }^{*} P<0.05,{ }^{\dagger} P<0.01$ and ${ }^{\ddagger} P<0.001$.

genes measured, but fetal plasma insulin was modestly negatively associated with $L P L, F A S N, H S L$ and UCP1 mRNA expression. In contrast, at gestational day 130, there were relatively weak negative relationships between fetal size, absolute PAT mass and gene expression for G3PDH and HSL (Table 4). Fetal weight-specific PAT mass was positively associated with $U C P 1$ gene expression, and this was the only relationship that was detected at both stages of gestation. UCP1 gene expression and carcass fat percentage were positively associated at day $130(n=14$; $r=0.559, P=0.039$ ). Fetal plasma glucose was positively related to leptin and all four of the IGF system genes at day 130 , and positive relationships were evident between fetal plasma insulin and both leptin and IGF1 gene expression.

PRLR gene expression was unrelated to fetal weight, adiposity or metabolic status at both stages of gestation (data not shown). Similarly, PRLR mRNA abundance was not related to the expression of any of the other genes measured in PAT. The relationships between the other 11 genes measured at gestational days 89 and 130 are detailed in Table 5. At day 89, robust positive relationships were evident between all possible comparisons $(n=21)$ of PPARG, G3PDH, LPL, FASN, HSL, leptin and UCP1 mRNA expression. At day 130, similar relationships were evident between PPARG, G3PDH, LPL and HSL, but none of these genes was related to FASN, UCP1 or leptin expression, and the latter genes were not correlated with each other. Similarly, IGF1 and IGF2 gene expression was positively related to the various genes involved in adipocyte differentiation and function at day 89 (reaching significance in 13 of 14 comparisons; Table 5), but it was unrelated to these genes at day 130. Selected examples of these relationships are detailed in Fig. 3.

\section{Adiposity and gene expression in relation to fetal sex}

An effect of sex per se on absolute or fetal weight-specific PAT mass was not detected at either gestational day 89 or 130 ( $P>0.3$, data not shown). In late gestation, females had relatively more unilocular fat mass than males did $(3.2 \pm 0.34 \mathrm{~g} / \mathrm{kg}$ vs $2.4 \pm 0.32 \mathrm{~g} / \mathrm{kg})$, but this was not statistically significant $(P=0.143)$. In relation to PAT gene expression, when sex was included as an additional factor in the ANOVA, females overall had greater leptin expression than males did $(P=0.001 ;$ Fig. $4 \mathrm{~A})$, and the impact of maternal nutrition as well as that of gestational age was significant $(P=0.029$ and $P=0.001$ respectively). Sex also influenced PAT $L P L$ gene expression
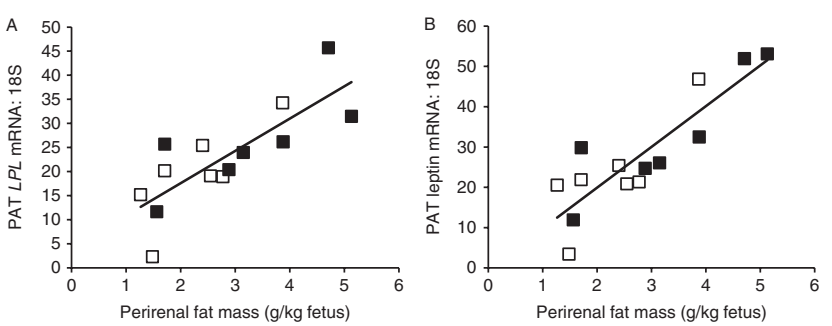

Figure 2

Relationships between body weight-specific perirenal adipose tissue (PAT) mass and perirenal fat $L P L$ mRNA $(A ; r=0.795, P<0.001)$ and leptin mRNA ( $B ; r=0.872, P<0.001$ ) at day 89 of gestation in fetuses from control (open square) and undernourished (filled square) adolescent dams.

Published by Bioscientifica Ltd. 
Table 5 Relationships between the relative expression of genes in perirenal fat at days 89 and 130 of gestation, irrespective of nutrition status or sex

\begin{tabular}{|c|c|c|c|c|c|c|c|c|c|c|}
\hline & G3PDH & LPL & FASN & HSL & Leptin & UCP1 & IGF1 & IGF2 & IGF1R & IGF2R \\
\hline \multicolumn{11}{|l|}{ Day 89} \\
\hline PPARG & $0.853^{\ddagger}$ & $0.910^{\ddagger}$ & $0.715^{\dagger}$ & $0.747^{\dagger}$ & $0.900^{\ddagger}$ & $0.768^{\dagger}$ & $0.940^{\ddagger}$ & $0.896^{\ddagger}$ & 0.593 * & $0.882^{\ddagger}$ \\
\hline G3PDH & & $0.754^{\dagger}$ & $0.677^{\dagger}$ & $0.693^{\dagger}$ & $0.845^{\ddagger}$ & $0.715^{\dagger}$ & $0.710^{\dagger}$ & $0.738^{\dagger}$ & 0.429 & $0.670^{\dagger}$ \\
\hline$L P L$ & & & $0.899^{\ddagger}$ & $0.891^{\ddagger}$ & $0.938^{\ddagger}$ & $0.754^{\dagger}$ & $0.805^{\ddagger}$ & $0.714^{\dagger}$ & 0.361 & $0.738^{\dagger}$ \\
\hline FASN & & & & $0.896^{\ddagger}$ & $0.833^{\ddagger}$ & $0.669^{\dagger}$ & 0.573 * & 0.468 & -0.023 & 0.422 \\
\hline$H S L$ & & & & & $0.868^{\ddagger}$ & $0.837^{\ddagger}$ & 0.603 * & 0.560 * & 0.124 & 0.515 \\
\hline Leptin & & & & & & $0.752^{\dagger}$ & $0.735^{\dagger}$ & $0.662^{\dagger}$ & 0.311 & $0.666^{\dagger}$ \\
\hline UCP1 & & & & & & & $0.663^{\dagger}$ & $0.626^{*}$ & 0.333 & 0.599 * \\
\hline$I G F 1$ & & & & & & & & $0.951^{\ddagger}$ & $0.686^{\dagger}$ & $0.927^{\ddagger}$ \\
\hline IGF2 & & & & & & & & & $0.776^{\ddagger}$ & $0.937^{\ddagger}$ \\
\hline IGF1R & & & & & & & & & & $0.874^{\ddagger}$ \\
\hline \multicolumn{11}{|l|}{ Day 130} \\
\hline PPARG & $0.653^{*}$ & $0.723^{\dagger}$ & 0.157 & $0.824^{\ddagger}$ & 0.242 & 0.171 & 0.118 & 0.345 & 0.548 * & 0.427 \\
\hline G3PDH & & $0.645^{*}$ & 0.189 & $0.713^{\dagger}$ & 0.347 & -0.113 & 0.192 & 0.356 & 0.252 & 0.321 \\
\hline$L P L$ & & & -0.008 & $0.716^{\dagger}$ & 0.222 & 0.006 & 0.014 & 0.155 & 0.502 & 0.245 \\
\hline FASN & & & & 0.099 & 0.129 & -0.047 & 0.348 & 0.337 & 0.000 & 0.193 \\
\hline$H S L$ & & & & & 0.220 & -0.217 & -0.166 & 0.087 & 0.181 & 0.150 \\
\hline Leptin & & & & & & 0.107 & 0.433 & 0.432 & 0.506 & 0.501 \\
\hline$U C P 1$ & & & & & & & 0.390 & 0.446 & 0.419 & 0.423 \\
\hline$I G F 1$ & & & & & & & & $0.934^{\ddagger}$ & 0.509 & $0.768^{\ddagger}$ \\
\hline IGF2 & & & & & & & & & 0.598 * & $0.896^{\ddagger}$ \\
\hline IGF1R & & & & & & & & & & $0.816^{\ddagger}$ \\
\hline
\end{tabular}

Values are Pearson correlation coefficients with significant values shown in bold, ${ }^{*} P<0.05,{ }^{\dagger} P<0.01$ and ${ }^{\ddagger} P<0.001$.

(females > males; Fig. 4B), and gene expression for both leptin and $L P L$ was lower in female but not male UN vs control fetuses at gestational day 89 only (Fig. 4A and B). Although an effect of sex was not detected for any of the other genes measured, PPARG mRNA expression was lower in UN vs control female fetuses at day 89 (nutrition $X$ stage $\times$ sex interaction, $P=0.011$ ).

\section{Discussion}

The present study revealed that a number of genes that regulate prenatal adipose tissue development and function are expressed by mid-gestation, at which point they
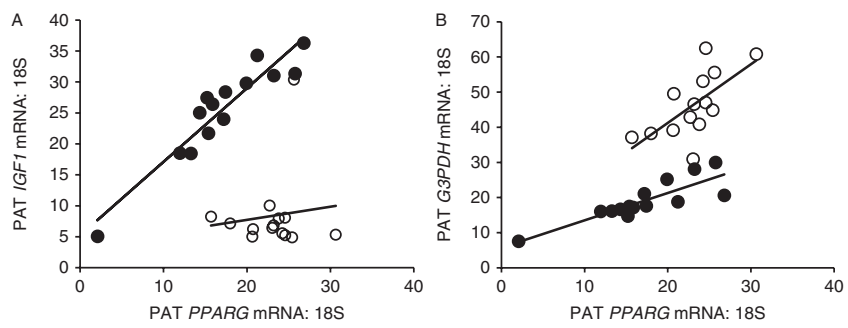

Figure 3

Relationships between relative PPARG gene expression and IGF1 (A), G3PDH (B), LPL (C) and leptin (D) mRNA in fetal perirenal adipose tissue (PAT) at day 89 (filled circle) and day 130 (open circle) of gestation. (A) Day 89: $r=0.940, P<0.001$ and day 130: $r=0.118$, not significant (NS).

http://jme.endocrinology-journals.org DOI: 10.1530/JME-15-0048 are already sensitive to maternal undernutrition, and that their expression levels are markedly changed by late gestation. Early molecular sensitivity to poor nutrient supply may underlie reduced fetal adiposity and altered proportions of unilocular and multilocular adipocytes, which are evident by late pregnancy. In addition, the present study indicates that some sex-specific differences in adipose tissue gene expression may emerge in utero.

\section{Fetal growth and adiposity}

Limiting maternal intake throughout gestation in young adolescent sheep has been shown to result in a gradual
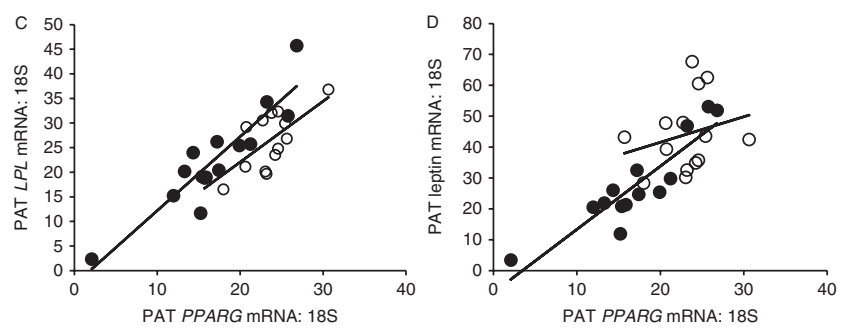

(B) Day 89: $r=0.853, P<0.001$ and day 130: $r=0.653, P<0.05$. (C) Day 89: $r=0.910, P<0.001$ and day 130: $r=0.723, P<0.01$. (D) Day 89: $r=0.900$, $P<0.001$ and day 130: $r=0.242$, NS. 

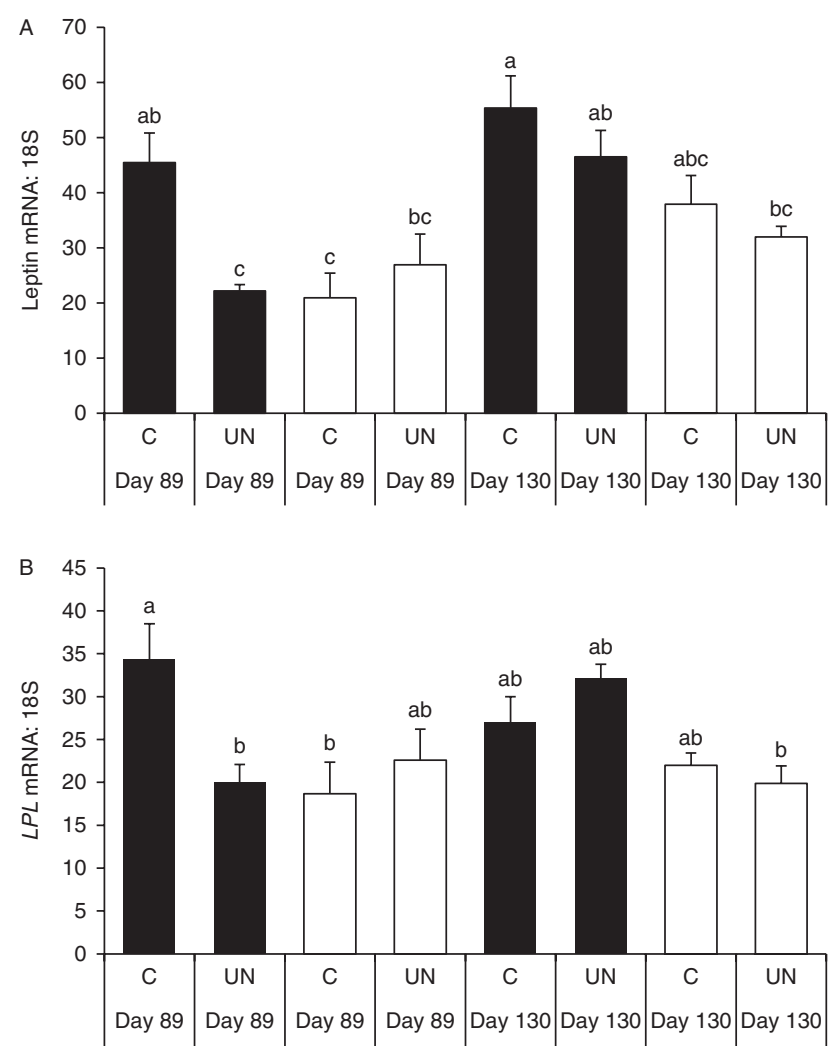

Figure 4

Relative leptin (A) and LPL (B) mRNA expression in fetal perirenal fat of female (solid bar) and male (open bar) fetuses from control (C) and undernourished (UN) adolescent dams whose pregnancies were terminated on day 89 or 130 of gestation. ANOVA was used to determine the effects of sex, maternal nutrition, stage of gestation and all possible interactions. Vertical bars are group means \pm s.E.M., and those with different letters differ at $P<0.05$ using Tukey's post hoc method. The number of fetuses per group can be derived from Table 2 . For leptin, there were effects of sex $(P=0.001)$, stage of gestation $(P=0.001)$, nutrition $(P=0.029)$ and a sex $\times$ nutrition interaction $(P=0.029)$. For $L P L$, there was an effect of sex $(P=0.002)$ and a sex $\times$ nutrition $\times$ stage of gestation interaction $(P=0.008)$.

depletion of maternal reserves and slower fetal growth. By late gestation, the fetuses of UN sheep were lighter and leaner than those of optimally nourished controls, as was reflected by lower carcass fat and reduced fetal PAT mass (Luther et al. 2007). In the present study, we demonstrated that the PAT mass reduction is primarily the result of lower numbers of unilocular adipocytes, which suggests that limiting maternal and hence fetal nutrient supply restricts the development of cells that are primarily involved in fat storage rather than cells that are involved in neonatal thermogenesis. The positive relationship between PAT unilocular fat mass and carcass fat content implies that a similar scenario likely operates throughout the fetus, and it leads to a lean body phenotype. However, although the impact of maternal undernutrition on weight at birth was statistically significant in the present model, the effect was modest, and previous studies that used an equivalent prenatal nutritional insult failed to detect persistent influences on postnatal growth or glucose metabolism up to 6 months of age (Wallace et al. 2010, 2012).

In the present study, a positive correlation between multilocular fat mass and fetal weight was observed within the UN group; furthermore, those fetuses had more multilocular than unilocular adipocytes, which may be indicative of developmental delay. Nevertheless, relative to the control group, maternal undernutrition did not influence absolute or relative multilocular cell mass overall, which suggests that if these pregnancies had progressed to term, neonatal thermogenesis might not have been severely compromised. Indeed, in two such studies, no neonatal mortality occurred in the offspring of UN dams following spontaneous delivery at term (Wallace 2011).

In the present UN paradigm, we restricted maternal intake throughout gestation rather than during specific 'windows', because this reflects the most common scenario in human pregnancy. We also focused on adolescents because insufficient gestational weight gain (a proxy for maternal undernutrition) in this age group predicts low birthweight (Hediger et al. 1989, Scholl et al. 1991, Stevens-Simon \& McAnarney 1992); in developing countries where malnutrition predominates, high pregnancy rates are commonplace in adolescents. As such, there is a lack of directly comparable data in other precocial animal models.

Previous studies of adipose tissue development have largely involved adult ewes UN during discrete windows of gestation, and there has been little consensus on the impact of undernourishment on fetal weight or PAT mass (Symonds et al. 1998, Bispham et al. 2003, Budge et al. 2004, Lie et al. 2013). None of these studies involving undernutrition quantified adipocyte cell populations, but conversely, when fetal nutrient supply in normal lategestation pregnancies was increased by a 10-day intrafetal glucose infusion, the unilocular fat mass was enhanced and the size of the dominant lipid locule was positively correlated with fetal glucose concentrations (Mühlhäusler et al. 2005). This last study and the data in the present study suggest that unilocular adipocytes within the PAT depot are sensitive to the prevailing nutrient supply in utero, and when this supply is compromised, multilocular cells predominate.

Published by Bioscientifica Ltd. 


\section{Perirenal fat gene expression: ontogeny and impact of undernutrition}

The design of the present study allowed us to examine for the first time both the ontogeny of fetal PAT gene expression and the impact of maternal undernutrition. At mid-gestation, when the adipose tissue first appears and begins to replicate, the abundance of all four IGF system genes was high, which is commensurate with the roles of IGF1 and IGF2 in adipocyte proliferation and differentiation (Holly et al. 2006, Kleiman et al. 2013). Moreover, at this early stage of PAT development, the relative gene expression of all four IGF system genes was already lower in UN fetuses as compared to control fetuses, before there was any significant reduction in fetal body weight or PAT mass. These observations are consistent with the attenuated IGF-mediated adipocyte proliferation and differentiation that occurred around mid-gestation, which most likely underlie the reduced mass and structural characteristics of PAT that were observed in the UN fetuses in late gestation. Although the consequences for postnatal body composition have not been established in this model, it is likely that the reduction in adipocyte number translates into an increased susceptibility for cellular hypertrophy in later life (Heilbronn et al. 2004), particularly if the animal is exposed to a nutrient-rich diet postnatally.

IGF1 regulates transcription factors, including PPARG (Scavo et al. 2004), and attenuated local IGF secretion within the developing PAT of UN fetuses may underlie the lower expression of PPARG at mid-gestation, which has consequences for the progression of adipocyte differentiation and function. The present data suggests that it is unlikely that deficits in glucose supply directly influence PPARG expression, because fetal plasma glucose was not different between the groups at mid-gestation, and no correlation between fetal glucose and PPARG mRNA was observed. In contrast, when maternal nutrition was increased in late pregnancy (55\% above maintenance), fetal plasma glucose and PAT PPARG mRNA were increased and positively correlated with each other independent of any changes in PAT mass or morphology (Mühlhäusler et al. 2007). IGF gene expression was not measured in this last study, but it is noteworthy that in the present study, fetal glucose was positively related to IGF system mRNA in late pregnancy.

Also in the present study, the gene expression of PPARG was modestly increased with gestational age. A similar ontogenic increase in PPARG expression has recently been reported in normally growing ovine fetuses sampled at either gestational day 80 or 140 (Pope et al. 2014), which is commensurate with its role as a key regulator of adipose tissue-specific genes and with the increase in PAT mass that occurs as gestation proceeds. Accordingly, a marked increase in relative gene expression between mid- and late gestation was observed here for selected genes involved in lipid deposition, metabolism and signalling (G3PDH, $H S L$ and leptin), whereas others involved in fatty acid synthesis and uptake into adipocytes (FASN and $L P L$ ) were surprisingly independent of gestational age.

For the genes specific to brown adipose tissue, namely $P R L R$ and UCP1, abundance was extremely low in midpregnancy and high at late pregnancy, which is in line with their role in promoting adequate thermogenesis after birth (Symonds et al. 1998, Pearce et al. 2005). Furthermore, the absence of an effect of maternal undernutrition on PRLR and UCP1 gene expression in the present lategestation fetuses matched the lack of an effect on multilocular adipocyte mass. Conversely, the trend for attenuated PAT gene expression in UN fetuses for leptin, a white adipose tissue-specific gene (Yuen et al. 2003), was in line with the observed reduction in unilocular cell mass in late gestation.

Irrespective of the direction of ontogenic change, and with the exception of the aforementioned leptin expression, it is noteworthy that none of the other genes measured was impacted only in late gestation by maternal undernutrition. This indicates that the key molecular events that underlie the lean fetal phenotype in this model originated earlier in gestation. In support of this idea, we observed robust positive correlations between fetal weight-specific PAT mass and genes involved in adipocyte differentiation and function at gestational day 89 (PPARG, G3PDH, LPL, FASN, HSL, leptin and UCP1), but by late gestation, only a weak relationship between UCP1 and adiposity persisted. Moreover, the expression of IGF1 and IGF2 was highly correlated with all of the aforementioned genes at the early stage of gestation, but fewer betweengene relationships were evident by late gestation. These findings may be attributable to the differentiation of adipose tissue into the two main cell types by late gestation and to the relative proportion of white vs brown adipocytes, which are differentially impacted by maternal undernutrition by that stage.

\section{Perirenal fat gene expression: impact of sex}

We did not originally power the present study to examine sex effects, because we had no control over the sex of the embryos at the time of their transfer into the adolescent recipients. Irrespective of the low power when the gene

Published by Bioscientifica Ltd. 
expression data were examined, it became clear that potentially interesting sex-specific effects were present. Accordingly, when sex was included as a factor in the analysis, both leptin and $L P L$ gene expression was higher in females than it was in males overall. This agrees with reported higher $L P L$ abundance in PAT and subcutaneous fat depots in female vs male lambs at 4 months postnatal age (Rattanatray et al. 2010). It also matches our data, which showed widespread sex differences in PAT gene expression, namely, higher $L P L, F A S N$ and leptin and lower IGF1, IGF2 and HSL in females, and it corresponds with the greater visceral and carcass fat depositions and larger adipocytes that were observed in females at 3 months of age (Wallace et al. 2014). Thus, the present study is the first in sheep to suggest that sex-specific differences in molecular markers of adipose tissue differentiation and/or function emerge in utero. We acknowledge that these potentially interesting sex differences in PAT gene expression require substantiation in larger and more suitably powered studies in the future. Nevertheless, the greater expression of leptin in female fetal PAT aligns with the prenatal sexual dimorphism in leptin secretion and neonatal adiposity in humans (females $>$ males). Relative to males, female sex is associated with greater leptin concentrations in amniotic samples at 16 weeks gestation and in cord blood at delivery (Cagnacci et al. 2006, Kayemba-Kay's et al. 2008) and with a greater percentage of body fat as measured by air-displacement plethysmography neonatally (Hawkes et al. 2011). Furthermore, only females in the present study were sensitive to the effects of maternal undernutrition with respect to $P P A R G$, leptin and $L P L$ gene expression at gestational day 89, which implies that a sensitivity to prevailing nutrition occurs earlier in females than it does in males, and there is likely to be a temporal difference in adipose tissue development between sexes throughout the early life course.

Previous studies that investigated the impact of maternal nutrition on prenatal adipose gene expression in precocial animals did not report fetal sex (Bispham et al. 2003, Budge et al. 2004, Mühlhäusler et al. 2007, Nguyen et al. 2010, Lie et al. 2013), but it is clearly an important consideration; imbalances in the male:female ratio may have confounded earlier results and may explain the lack of consensus in the sheep literature. Indeed, sexually dimorphic differences in fetal growth and the expression of genes involved in adipogenesis and brown adipose tissue development following in vitro adipocyte differentiation in culture have been seen in fetal baboons following modest maternal undernutrition throughout gestation (Tchoukalova et al. 2014). Although we did not determine the long-term impact of the mid-gestation sexspecific nutritional sensitivity of adipose tissue gene expression on postnatal adiposity, the present data align with findings from studies of the Dutch famine of 1945. These showed that maternal famine exposure during early (but not mid- or late) pregnancy was associated with greater BMI and waist circumference at age 50 in women but not in men (Ravelli et al. 1999), and this may be a result of the altered DNA methylation of genes involved in adipose tissue metabolism (Tobi et al. 2009).

In conclusion, these data support the hypothesis that molecular markers of adipose tissue development in the fetus are temporally sensitive to maternal undernutrition in precocial mammals. Some key genes that regulate adipose tissue development and function are active beginning in mid-gestation, at which point they are variously sensitive to maternal undernutrition and can lead to reduced fetal adiposity in late gestation. Furthermore, sex-specific differences in adipose tissue gene expression emerge in fetal life. Whether these prenatal events impact body composition in adult life remains unknown, but it is clear that ensuring adequate maternal nutrition beginning in the earliest stages of pregnancy is essential for optimising fetal growth and neonatal adipose development.

\section{Declaration of interest}

The authors declare that there is no conflict of interest that could be perceived as prejudicing the impartiality of the research reported.

\section{Funding}

The present study was funded by the Scottish Government's Rural and Environment Science and Analytical Services Division (RESAS), including the Strategic Partnership for Animal Science Excellence (SPASE) and the U.S. National Institutes of Health (grant number HD045784).

\section{References}

AFRC 1993 Energy and Protein Requirements of Ruminants. An Advisory Manual Prepared by the AFRC Technical Committee on Responses to Nutrients. Wallingford, Oxfordshire, UK: CAB International.

Bispham J, Gopalakrishnan GS, Dandrea J, Wilson V, Budge H, Keisler DH, Broughton Pipkin F, Stephenson T \& Symonds ME 2003 Maternal endocrine adaptation throughout pregnancy to nutritional manipulation: consequences for maternal plasma leptin and cortisol and the programming of fetal adipose tissue development. Endocrinology 144 3575-3585. (doi:10.1210/en.2003-0320)

Budge H, Edwards LJ, McMillan IC, Bryce A, Warnes K, Pearce S, Stephenson T \& Symonds ME 2004 Nutritional manipulation of fetal adipose deposition and uncoupling protein 1 messenger RNA abundance in the sheep: differential effects of timing and duration.

Published by Bioscientifica Ltd. 
Biology of Reproduction 71 359-365. (doi:10.1095/biolreprod.103. 018986)

Cagnacci A, Arangino S, Caretto S, Mazza V \& Volpe A 2006 Sexual dimorphism in the levels of amniotic fluid leptin in pregnancies at 16 weeks gestation: relation to fetal growth. European Journal of Obstetrics, Gynecology, and Reproductive Biology 124 53-57. (doi:10.1016/ j.ejogrb.2005.05.009)

Christian P, Murray-Kolb LE, Tielsch JM, Katz J, LeClerq SC \& Khatry SK 2014 Associations between preterm birth, small-for-gestational age, and neonatal morbidity and cognitive function among school-age children in Nepal. BMC Pediatrics 14 58. (doi:10.1186/ 1471-2431-14-58)

Galic S, Oakhill JS \& Steinberg GR 2010 Adipose tissue as an endocrine organ. Molecular and Cellular Endocrinology 25 129-139. (doi:10.1016/ j.mce.2009.08.018)

Gemmell RT \& Alexander G 1978 Ultrastructural development of adipose tissue in foetal sheep. Australian Journal of Biological Sciences $\mathbf{3 1}$ 505-515.

Greenwood PL, Thompson AN \& Ford SP 2010 Postnatal consequences of the maternal environment and growth during prenatal life for productivity of ruminants. In Managing the Prenatal Environment to Enhance Livestock Productivity, pp 3-36. Eds PL Greenwood, AW Bell, PE Vercoe \& GJ Viljoen. Dordrecht, Netherlands: Springer. (doi:10.1007/978-90-481-3135-8).

Hawkes CP, Hourihane JO, Kenny LC, Irvine AD, Kiely M \& Murray DM 2011 Gender- and gestational age-specific body fat percentage at birth. Pediatrics 128 e645-e651. (doi:10.1542/peds.2010.3856)

Hediger ML, Scholl TO, Belsky DH, Ances IG \& Salmon RW 1989 Patterns of weight gain in adolescent pregnancy: effects on birth weight and preterm delivery. Obstetrics and Gynecology 74 6-12.

Heilbronn L, Smith SR \& Ravussin E 2004 Failure of fat cell proliferation, mitochondrial function and fat oxidation results in ectopic fat storage, insulin resistance and type II diabetes mellitus. International Journal of Obesity 28 (Suppl 4) S12-S21. (doi:10.1038/sj.ijo.0802853)

Holly J, Sabin M, Perks C \& Shield J 2006 Adipogenesis and IGF-1. Metabolic Syndrome and Related Disorders 4 43-50. (doi:10.1089/met.2006.4.43)

Jain V \& Singhal A 2012 Catch up growth in low birth weight infants: striking a healthy balance. Reviews in Endocrine \& Metabolic Disorders 13 141-147. (doi:10.1007/s11154-012-9216-6)

Kayemba-Kay's S, Geary MP, Pringle J, Rodeck CH, Kingdom JC \& Hindmarsh PC 2008 Gender, smoking during pregnancy and gestational age influence cord leptin concentrations in newborn infants. European Journal of Endocrinology 159 217-224. (doi:10.1530/ EJE-08-0171)

Klaus S 2004 Adipose tissue as a regulator of energy balance. Current Drug Targets 5 241-250. (doi:10.2174/1389450043490523)

Kleiman A, Keats EC, Chan NG \& Khan ZI 2013 Elevated IGF2 prevents leptin induction and terminal adipocyte differentiation in hemangioma stem cells. Experimental and Molecular Pathology 94 126-136. (doi:10.1016/j.yexmp.2012.09.023)

Lie S, Morrison JL, Williams-Wyss O, Ozanne SE, Zhang S, Walker SK, Kleeman DO, MacLaughlin SM, Roberts CT \& McMillen IC 2013 Impact of embryo number and periconception undernutrition on factors regulating adipogenesis, lipogenesis, and metabolism in adipose tissue in the sheep fetus. American Journal of Physiology. Endocrinology and Metabolism 305 E931-E941. (doi:10.1152/ajpendo.00180.2013)

Longo S, Bollani L, Decembrino L, Di Comite A, Angelini M \& Stronati M 2013 Short-term and long-term sequelae in intrauterine growth retardation (IUGR). Journal of Maternal-fetal \& Neonatal Medicine 26 222-225. (doi:10.3109/14767058.2012.715006)

Lukaszewski MA, Eberlé D, Vieau D \& Breton C 2013 Nutritional manipulation in the perinatal period program adipose tissue in offspring. American Journal of Physiology. Endocrinology and Metabolism 305 E1195-E1207. (doi:10.1152/ajpendo.00231.2013)

Luther JS, Redmer DA, Reynolds LP \& Wallace JM 2005 Nutritional paradigms of ovine fetal growth restriction: implications for human pregnancy. Human Fertility 8 179-187. (doi:10.1080/ 14647270500320121)

Luther J, Aitken R, Milne J, Matsuzaki M, Reynolds L, Redmer D \& Wallace J 2007 Maternal and fetal growth, body composition, endocrinology, and metabolic status in undernourished adolescent sheep. Biology of Reproduction 77 343-350. (doi:10.1095/biolreprod. 107.061440)

MacRae JC, Bruce LA, Hovell FD, Hart IC, Inkster J \& Atkinson T 1991 Influence of protein nutrition on the response of growing lambs to exogenous bovine growth hormone. Journal of Endocrinology 130 53-61. (doi:10.1677/joe.0.1300053)

Matsuzaki M, Milne JS, Aitken RP \& Wallace JM 2006 Overnourishing pregnant adolescent ewes preserves perirenal fat deposition in their growth-restricted fetuses. Reproduction, Fertility, and Development 18 357-364. (doi:10.1071/RD05067)

Moragas A \& Toran N 1983 Prenatal development of brown adipose tissue in man. A morphometric and biomathematical study. Biology of the Neonate 43 80-85. (doi:10.1159/000241641)

Mühlhäusler BS, Roberts CT, McFarlane JR, Kauter KG \& McMillen IC 2002 Fetal leptin is a signal of fat mass independent of maternal nutrition in ewes fed at or above maintenance energy requirements. Biology of Reproduction 67 493-499. (doi:10.1095/biolreprod67.2493)

Mühlhäusler BS, Adam CL, Marrocco EM, Findlay PA, Roberts CT, McFarlane JR, Kauter KG \& McMillen IC 2005 Impact of glucose infusion on the structural and functional characteristics of adipose tissue and on hypothalamic gene expression for appetite regulatory neuropeptides in the sheep fetus during late gestation. Journal of Physiology 565 185-195. (doi:10.1113/jphysiol.2004.079079)

Mühlhäusler BS, Duffield JA \& McMillan IC 2007 Increased maternal nutrition stimulates peroxisome proliferator activated receptor- $\gamma$, adiponectin, and leptin messenger ribonucleic acid expression in adipose tissue before birth. Endocrinology 148 878-885. (doi:10.126/ en.2006-1115)

Nguyen LT, Mühlhäusler BS, Botting KJ \& Morrison JL 2010 Maternal undernutrition alters fat cell size distribution, but not lipogenic gene expression, in the visceral fat of the late gestation guinea pig fetus. Placenta 31 902-909. (doi:10.1016/j.placenta.2010.07.014)

Nissen PM \& Oksbjerg N 2010 Quantification of prenatal effects on productivity in pigs. In Managing the Prenatal Environment to Enhance Livestock Productivity, pp 37-70. Eds PL Greenwood, AW Bell, PE Vercoe \& GJ Viljoen. Dordrecht, Netherlands: Springer. (doi:10.1007/978-90481-3135-8).

Pearce S, Budge H, Mostyn A, Genever E, Webb R, Ingleton P, Walker AM, Symonds ME \& Stephenson T 2005 Prolactin, the prolactin receptor and uncoupling protein abundance and function in adipose tissue during development in young sheep. Journal of Endocrinology $\mathbf{1 8 4}$ 351-359. (doi:10.1677/joe.1.05732)

Pope M, Budge H \& Symonds ME 2014 The developmental transition of ovine adipose tissue through early life. Acta Physiologica 210 20-30. (doi:10.1111/apha.12053)

Raqib R, Alam DS, Sarker P, Ahmad SM, Ara G, Yunus M, Moore SE \& Fuchs G 2007 Low birth weight is associated with altered immune function in rural Bangladeshi children: a birth cohort study. American Journal of Clinical Nutrition 85 845-852.

Rattanatray L, MacLaughlin SM, Kleeman DO, Walker SK, Mühlhäusler BS \& McMillen IC 2010 Impact of maternal periconceptional overnutrition on fat mass and expression of adipogenic and lipogenic genes in visceral and subcutaneous fat depots in the postnatal lamb. Endocrinology 151 5195-5205. (doi:10.1210/en.2010-0501)

Ravelli AC, van der Meulen JH, Osmond C, Barker DJ \& Bleker OP 1999 Obesity at the age of $50 \mathrm{y}$ in men and women exposed to famine prenatally. American Journal of Clinical Nutrition 70 811-816.

Russel AJF, Doney JM \& Gunn RG 1969 Subjective assessment of body fat in live sheep. Journal of Agricultural Science 72 451-454. (doi:10.1017/ S0021859600024874) 
Sarr O, Yang K \& Regnault TRH 2012 In utero programming of later adiposity: the role of fetal growth restriction. Journal of Pregnancy $\mathbf{2 0 1 2}$ Article ID 134758, 10 pages. (doi:10.1155/2012/134758)

Scavo LM, Karas M, Murray M \& Leroith D 2004 Insulin-like growth factor1 stimulates both cell growth and lipogenesis during differentiation of human mesenchymal stem cells into adipocytes. Journal of Clinical Endocrinology and Metabolism 89 3543-3553. (doi:10.1210/ jc.2003-031682)

Scholl TO, Hediger ML, Khoo CS, Healey MF \& Rawson NL 1991 Maternal weight gain, diet and infant birth weight: correlations during adolescent pregnancy. Journal of Clinical Endocrinology 44 423-428. (doi:10.1016/0895-4356(91)90081-J)

Semple RK, Chatterjee VK \& O'Rahilly S 2006 PPAR $\gamma$ and human metabolic disease. Journal of Clinical Investigation 116 581-590. (doi:10.1172/ JCI28003)

Stevens-Simon C \& McAnarney ER 1992 Adolescent pregnancy. Gestational weight gain and maternal and infant outcomes. American Journal of Diseases and Children 146 1359-1364. (doi:10.1001/archpedi. 1992.02160230117031)

Symonds ME 2013 Brown adipose tissue growth and development. Scientifica 2013 Article ID 305763, 14 pages. (doi:10.1155/2013/ 305763)

Symonds ME, Phillips ID, Anthony RV, Owens JA \& McMillen IC 1998 Prolactin receptor gene expression and foetal adipose tissue. Journal of Neuroendocrinology 10 885-890. (doi:10.1046/j.1365-2826.1998.00275.x)

Tchoukalova YD, Krishnapuram R, White UA, Burk D, Fang X, Nijland MJ \& Nathanielsz PW 2014 Fetal baboon sex specific outcomes in adipocyte differentiation at 0.9 gestation in response to moderate maternal nutrient reduction. International Journal of Obesity $\mathbf{3 8}$ 224-230. (doi:10.1038/ijo.2013.106)

Tobi EW, Lumey LH, Talens RP, Kremer D, Putter H, Stein AD, Slagboom PE \& Heijmans BT 2009 DNA methylation differences after exposure to prenatal famine are common and timing- and sex-specific. Human Molecular Genetics 18 4046-4053. (doi:10.1093/hmg/ddp353)

Wallace JM 2011 Adaptive maternal, placental and fetal responses to nutritional extremes in the pregnant adolescent: lessons from sheep
In Reproduction and Adaptation, pp 112-127. Eds CGN Mascie-Taylor \& LL Rosetta. Cambridge, UK: Cambridge University Press.

Wallace JM, Da Silva P, Aitken RP \& Cheyne MA 1997 Maternal endocrine status in relation to pregnancy outcome in rapidly growing adolescent sheep. Journal of Endocrinology 155 359-368. (doi:10.1677/joe.0. 1550359)

Wallace JM, Bourke DA, Aitken RP \& Cruickshank MA 1999 Switching maternal dietary intake at the end of the first trimester has profound effects on placental development and foetal growth in adolescent ewes carrying singleton fetuses. Biology of Reproduction 61 101-110. (doi:10.1095/biolreprod61.1.101)

Wallace JM, Matsuzaki M, Milne J \& Aitken R 2006 Late but not early gestational maternal growth hormone treatment increases fetal adiposity in overnourished adolescent sheep. Biology of Reproduction $\mathbf{7 5}$ 231-239. (doi:10.1095/biolreprod.106.052605)

Wallace JM, Milne JS \& Aitken RP 2010 Effect of weight and adiposity at conception and wide variations in gestational dietary intake on pregnancy outcome and early postnatal performance in young adolescent sheep. Biology of Reproduction 82 320-330. (doi:10.1095/ biolreprod.109.080069)

Wallace JM, Milne JS, Adam CA \& Aitken RP 2012 Adverse metabolic phenotype in low-birth-weight lambs and its modification by postnatal nutrition. British Journal of Nutrition 107 510-522. (doi:10.1017/ S0007114511003175)

Wallace JM, Milne JS, Aitken RP \& Adam CL 2014 Influence of birth weight and gender on lipid status and adipose tissue gene expression in lambs. Journal of Molecular Endocrinology 53 131-144. (doi:10.1530/ JME-14-0123)

Wiebel ER 1979 Practical methods for biological morphometry. In Stereological Methods, vol 1. London, UK: Academic Press.

Wu G, Bazer FW, Wallace JM \& Spencer TE 2006 Board-invited review: Intrauterine growth retardation: implications for the animal sciences. Journal of Animal Science 84 2316-2337. (doi:10.2527/jas.2006-156)

Yuen SJ, Owens PC, Mühlhäusler BS, Roberts CT, Symonds ME, Keisler DH, McFarlane JR, Kauter KG, Evens Y \& McMillan IC 2003 Leptin alters the structural and functional characteristics of adipose tissue before birth. FASEB Journal 17 1102-1104. (doi:10.1096/fj.02-0756fje)

Received in final form 17 April 2015

Accepted 24 April 2015

Accepted Preprint published online 27 April 2015
(C) 2015 Society for Endocrinology Printed in Great Britain 